\title{
The Feasibility of Implementing a Secure C2C Credit Scoring Platform
}

\author{
Mariam Musa Al- oqabi ${ }^{1}$, Dr. Wahid Rajeh ${ }^{2}$ \\ Department of Information Technology \\ University of Tabuk \\ Faculty of Computers and Information Technology \\ Saudi Arabia, Tabouk
}

\begin{abstract}
The continuous development of social media and online commerce, which permeates all aspects of our lives, leads to the need for a similar mechanism similar to the financial credit score in traditional business. Also, a realistic classification of users through social media to be used in all aspects of the relationships between users and some of them or between them and organizations is needed. In this article a new metrics to classify users according to their creditworthiness of the transactions that take place through the Internet is established. The object from this aricle design a social credit system model (SCSM) based on these new metrics. How to deal on the Internet, attacking people on social media, violating the privacy of people and others. Also Buying and selling operations, executing purchase and sale orders, paying amounts of money easily and quickly, and so on. These data and their degree of importance were determined according to several questionnaires directed to several segments of society. This creditworthiness can be used in banks, Uber, Online transactions and so on.
\end{abstract}

Keywords-Social media; online commerce; social credit system; creditworthiness

\section{INTRODUCTION}

The increase in credit fraud in the information age has disrupted economic market activities and could cause significant damage to global economic systems. This lead researcher to study a social credit and assess credit risk by scoring each user based on objective measures.

This study is mainly done to build a SCSM model which gains importance from the need to facilitate all operations that take place over the Internet.

Social media can be defined as a Web based information system that allows users to create profiles, support communication between users, and create relationships [1]. Loans, financial transactions and credit cards need certain conditions to approve these transactions. These conditions are known nowadays as people's creditworthiness. Companies and banks rely on home address, income, job data and so on to determine the creditworthiness of people. Also, the way to pay its past payments will greatly affect its creditworthiness, which allows or does not allow it to take a loan or get a credit card. Traditional data in our time is insufficient to build creditworthiness, Using social data is one such option [2]. It is needed in all online transactions. The individual's profile data on social networks such as Facebook, largely reflects the real data of the person who can be used to build creditworthiness
[3]. Building a social credit system based on these ideas can improve all Traditional and online financial transactions. This system will add confidence to all online processes. There is various example that may benefit from social credit scoring, for instances you can accept a friend on Facebook based on his social credit. There are multi ways people interact with the consumer credit system, more specifically, the way they access credit and the way they are held accountable for their debt [4]. Microfinance has been taken care of and how to ensure credit evaluation. In addition to traditional credit rating methods such as sociodemographic and credit data, other data from Facebook (like group, friends, and so on) has been extracted and used in a new model to automate the credit scoring process for microfinance [5]. The impact of using metrics based on social networks has been analyzed to give a score to customers is illustrated in [6]. Goel and Gold stein in [7], discussed using the available data through social media to show people's trends in purchasing, clicking on ads and registering in different events. They rely on friend-to-friend relations to make the decision and categorize people. This relationship on social media predicts a user's behavior by tracking a friend's behavior in purchases, clicking and any online transaction. The Chinese system of social credit has been designed to target many fields [8], [9]. The social credit scores are routinely incorporated to include most information about the people, so it's affect on get job, even dating or marriage, it become active to structure the people's life [10], [11]. These are aimed at judicial and other credibility in the fight against fraud. There is also another goal of building social community loyalty to increase trust among individuals. Social credit information is collected by specific parties, ranging from administrative sanctions, payments, volunteering, web searches, social media comments, GPS tracking data and most online transaction data. This system expands the information collected and the goals in which this system is used. This data is comprehensive and not important to our primary goal of building creditworthiness for online transactions. Researchers in [12], relied on a collection of social media data collected through the most popular Chinese website Weibo. This data mainly includes demographics, tweets, and people-to-people relationships. They apply some machine learning techniques to predict the credit score of a person. In [13], how to rely on people-to-people relationships on social networks in the distribution of new products has been studied. The point was also made that with more information on social networks, the marketing process would be accurate. Infer the degree of 
credit for people from their online social data studied at [14]. A model for learning about online user behavior, especially via Twitter, has been suggested as illustrated in Fig. 1. In it, the tweets are analyzed and the words discovered to classify people credit. For example, as described in the figure, the same drunken habits and watching football matches are associated with sending late-night tweets. Accordingly, the system can predict certain behavioral habits of users, and on the basis of these habits can be credited through social media. In Research [15], [16], work is done to identify the most influential social media users in the activities of others in order to draw greater advertising and administrative attention to them. In 2014-2020 the Chinese government intend to build social credit system (SCS) to better collect and evaluate citizens' creditworthiness, and grant rewards and punishments based on one's social credit. They built the SCS depend on collect information from national development and perform commission, Supreme People's Court, other Central Governmental Agencies, and the other Government Agencies Bank of China and others benefit from this information to judgment on the people from are this people in redlist or discredited judgment debtor [17]. China's Internet market was examined in [18], [19], where social-media data were used to describe borrowers' behavior and how credit rating systems can influence social behavior in china's social credit systems, it's research in concepts of an ideal citizen, the state and associated private enterprises can reinforce trust within society by issuing social credit scores to everyone, so everyone will likely aim to achieve a high social credit score, but the government state need to consider the implications of their policies and consider avenues that individual for low social credit scores could turn towards for assistance.

This article was based on the development of multiple models to compare the accuracy of customer scores obtained based on social networks or without. It relied on the efforts of lawyers and data scientists who extract credit worthiness from the big data available online in most social network sites. Legal problems have also been analyzed and solutions are found for all these problems to ensure transparency and trust. From the previous, we noted a lack of processing some concepts that must be dealt with to produce a robust system that can reflect an individual's true creditworthiness. Violating the privacy of people and other social media events and linking social media to e-commerce sites to assess people's transactions is our goal. In addition, a model will be built in which the type of data is determined and how it is collected, analyzed, and used to build the creditworthiness. Also, this article different from others, specific data will not be analyzed for creditworthiness, but will be designed a model adjust what data can be collected or added and how it will be used to accurately grant people credit. This model collect data from multi sources such as social networks, online sales and purchases data about the individual, in order to classify individuals in terms of creditworthiness.

This article organizes as follows: In section introduction, we talked about the literature review and display the difference between this article and others and the features this article has. The methodology used in collect the data are discussed in section Methodology. The analysis the questionnaire content and get the results are explained in results and discussion section. In section design SCSM, talked about the design the model. In section conclusion, displayed the conclusion we got from this article.

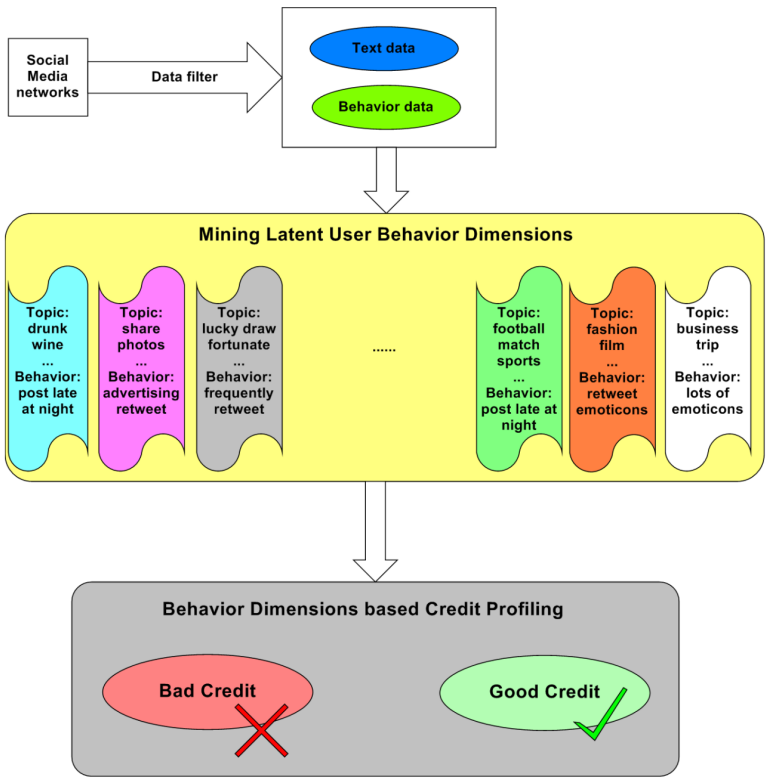

Fig. 1. Credit Score Based on Social Data.

\section{Methodology}

This article depend on the questionnaire. So, in order to gather needed information from the society, two-part questionnaire is designed using Google Docs and URL. The questionnaire was distributed online by WhatsApp, Instagram, and Telegram social media users. The questionnaire distributed to a number of specialists on banking, service providers and other peoples. It will be taken into consideration that the subscribers familiar with regulations, laws and banks and a fair distribution in terms of age and gender. The questionnaires designed to three groups:

1) The first for ordinary internet and social users.

2) The second for companies and service providers via the Internet or in traditional ways.

3) Finally, for those familiar with the work of banks.

By using Likert questionnaires, the data can be collected quickly and this data can also be interpreted and relied on it [20]. Here this type of measure will be used to collect the exact respondent's opinion on specific points. It allows us to build our model accurately. The advantages of the Likert scale questions in surveys is that:

- It is an accurate way to collect data, through which you can analyze and understand data well.

- It can be used with quantitative data.

- It is easy to conduct it as it does not take time.

- Multiple options, allowing accurate answers from respondents.

In this article a 6-point measures will be used as illustrated in table I, as they increase the accuracy of the answer. The scale combines answers that vary from weaker (Strongly disagree) to strongly agree support. To increase the accuracy of the questionnaire results, this scale does not have a neutral answer 
to obtain weighted answers from all participants. Another type of question (yes / no) is used in this article to specifically measure the participants' opinion on some issues related to financial transactions over the Internet and the legality of tracking users' information over the Internet. The volunteers were requested to answer the question are listed in Appendix A.

total of 600 respondents answered the survey questions. In this dataset, rows represent different type of events and column different criteria for analysis. Each data record represents the value of a particular analysis criterion for a type of event. Based on the data obtained from the survey, a dataset are organized using excel tool. The next step was sampling the data in order to prepare them for further analysis. Based on the results of this questionnaires and the previous literature review, a SCSM will be designed.

TABLE I. A SAMPLE 6-POINT LiKeRT SCALE

\begin{tabular}{|lll|}
\hline & likert scale & \\
\hline Srtongly Disagree & Disagree & Slightly Disagree \\
Slightly Agree & Agree & Strongly Agree \\
\hline
\end{tabular}

\section{RESUlTS AND DisCUSSION}

This section contains the results and discussion of all questionnaire.

1) Results and discussion of the first questionnaire: Table II, explains responses obtained from respondents; the percentage response was calculated in line with the 6-likert scale.

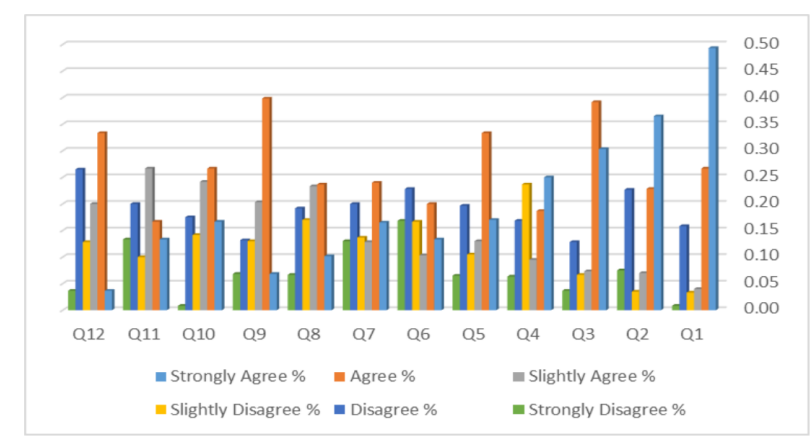

Fig. 2. Percentage Results of Internet and Social Users Questionnaire Likert Part.

As shown in fig. 2, for the first question, a large percentage of people agreed that they use the Internet a lot, where the percentage of Strongly Agree was $49 \%$ for this question. The overall approval rate was approximately $80 \%$, which supports us in providing the proposed model for classify internet users. Also, even if it was less, the respondents agreed in the second question that they use social media frequently a lot, which will support our proposed model based on social media for extracting data on individuals. The results for the third question are Strongly Agree 30\%, Agree 39\%, Slightly Agree 7\%, Slightly Disagree 7\%, Disagree 13\%, Strongly Disagree $4 \%$. Regarding this question, the high approval rate indicates the future of Internet commerce and that it will expand rapidly and continuously. Participants have been responding to the fourth question with percentage Strongly Agree 25\%, Agree $19 \%$, Slightly Agree $10 \%$. These ratios make us predict that the information available from users' interactions through the Internet will be rich and sufficient to build our model. The approval rate $(63 \%)$ for the fifth question opens up different methods for us to obtain accurate data on individuals to be accurately evaluated through our proposed model. Since the use of such applications as the Uber application provides us with more information on the behavior of individuals. The sixth and seventh questions are concerned with studying the degree of problems that individuals face in buying and selling through the Internet. The percentage of problems encountered when selling transaction by individuals on the Internet is higher than in purchasing transaction, and this mainly results from the lack of experience of individuals in selling via the Internet. Generally, these questions indicate the existence of actual problems when applying transaction via the Internet: Strongly Agree 13\%, Agree 20\%, Slightly Agree 10\% for question six and Strongly Agree 17\%, Agree 24\%, Slightly Agree 13\% for the seventh question.

Questions from 8 to 10 are concerned with studying the existence of verbal and psychological attacks, privacy violation, and data theft. The rate of expectation of a privacy violation problem is higher than the other two problems, where the overall approval rate is $61 \%$. Respondents' answers for these three questions support the need for the model presented in this article.

The eleventh question measure the prevalence of banking transactions that take place over the Internet. Of course, there is a percentage that has a weight that does not use these services, due to fear of problems with online transactions. Finally, the twelfth question is one of the most important questions, as it measures the opinions of the participants regarding the possibility of using the transactions that take place through the Internet and social media in building a creditworthiness system similar to that found in banks.

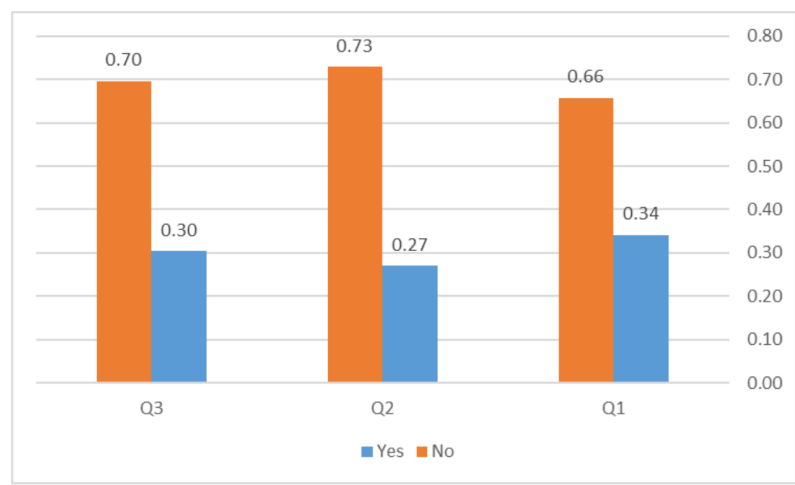

Fig. 3. Percentage Results of Internet and Social Users Questionnaire Yes/No Part.

Fig. 3, illustrate the three (Yes / No) questions that display Internet users in general. Table III, contains the respondent's answers. it given to users to measuring their opinion specifically about the problems they face when selling (such as eBay) or buying. It is noticeable in Fig. 3, that the product quality problems were approved by a number of subscribers, close to $34 \%$. Also, the problems of buying and selling via the 
(IJACSA) International Journal of Advanced Computer Science and Applications,

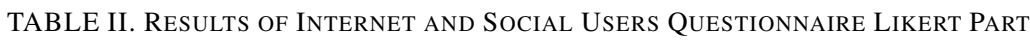

\begin{tabular}{|c|c|c|c|c|c|c|c|c|}
\hline Questions & $\begin{array}{l}\text { Strongly } \\
\text { Agree }\end{array}$ & Agree & $\begin{array}{l}\text { Slightly } \\
\text { Agree }\end{array}$ & $\begin{array}{l}\text { Slightly } \\
\text { Disagree }\end{array}$ & Disagree & $\begin{array}{l}\text { Strongly } \\
\text { Disagree }\end{array}$ & Total Response & Results \\
\hline Using Internet & 296 & 160 & 24 & 20 & 95 & 5 & 600 & Accepted \\
\hline Using Social Media & 219 & 137 & 42 & 21 & 136 & 45 & 600 & accepted \\
\hline Buying Product & 182 & 235 & 44 & 40 & 77 & 22 & 600 & accepted \\
\hline Purchases and Sales & 150 & 112 & 57 & 142 & 101 & 38 & 600 & Accepted \\
\hline Using Uber & 102 & 200 & 78 & 63 & 118 & 39 & 600 & Accepted \\
\hline Problem During Sales & 80 & 120 & 62 & 100 & 137 & 101 & 600 & Not Accepted \\
\hline Problem During Buying & 99 & 144 & 77 & 82 & 120 & 78 & 600 & Accepted \\
\hline Verbal and Psychological Attacks & 61 & 142 & 140 & 102 & 115 & 40 & 600 & Accepted \\
\hline Violating Privacy & 41 & 239 & 122 & 78 & 79 & 41 & 600 & Accepted \\
\hline Stolen Personal Data & 100 & 160 & 145 & 85 & 105 & 5 & 600 & Accepted \\
\hline Banking Transactions Online & 80 & 100 & 160 & 60 & 120 & 80 & 600 & Accepted \\
\hline Extract Information for Creditworthiness & 22 & 200 & 120 & 77 & 159 & 22 & 600 & Accepted \\
\hline
\end{tabular}

TABLE III. INTERNET AND SOCIAL USERS QUESTIONNAIRE - YES/NO PART

\begin{tabular}{llll}
\hline Questions & Yes & No & Total Response \\
\hline Quality Problem & 205 & 395 & 600 \\
Financial Problems at Selling & 162 & 438 & 600 \\
Financial Problems at Buying & 182 & 418 & 600 \\
\hline
\end{tabular}

Internet had support, but less than the quality problems. These problems are mainly found because there is no real evaluation that reflects users' behavior online.

An important question was asked to Participants about how to pay the value of goods purchased over the Internet. The classification of the answers is shown in Table IV, Also, Fig. 4 , shows the percentage of each choice. As shown, payment on receipt is the predominant feature with a good percentage that uses the visa in its online purchasing transactions. This result is due to the fear of a large percentage of participants from using their credit card over the Internet. Also, this supports our need for the proposed model in our article.

TABLE IV. RESUlTS OF INTERNET AND SOCIAL USERS QUESTIONNAIRE CHOOSE PART

\begin{tabular}{llll}
\hline Question ID & Visa & $\begin{array}{l}\text { when re- } \\
\text { ceiving }\end{array}$ & Total Response \\
\hline Payment Method & 12 & 18 & 30 \\
\hline
\end{tabular}

2) Results and discussion of the second questionnaire: The questions directed to companies, that apply their transaction through the Internet, measure the extent of the difficulties they face, whether there is a need to make rating of Internet users and what are the basic data that can be used in this rating process. Table $\mathrm{V}$, contains the answers of 30 participants in this questionnaire.

As shown in Fig. 4, the first question measures the extent to which the company uses the Internet to apply their commercial transactions. Answers show that approval responses slightly outweigh disagreement. This is a result of the fear of conducting these transactions, as there is no accurate rating of the person you are dealing with. The answer to the third question may be related to the first question. As is the case with

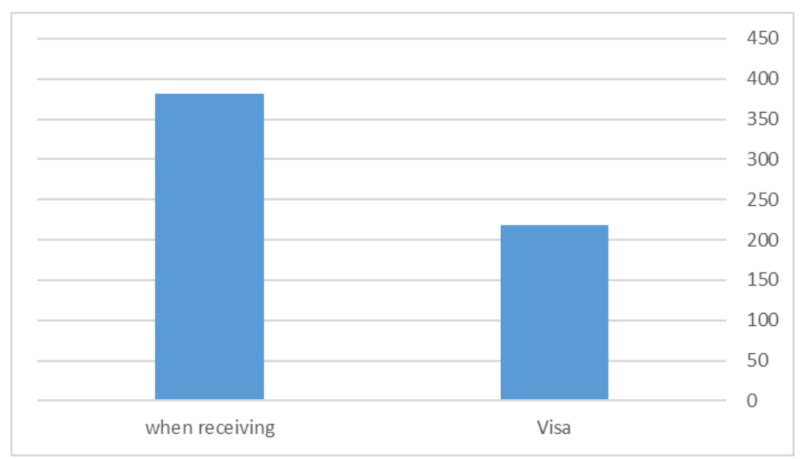

Fig. 4. Percentage Results of Internet and Social Users Questionnaire Choose Part.

a number of participants who are not using online business transactions, they are likely to see no income from the Internet.

Returning to the second question, the respondents 'answers fluctuate between approval and disapproval (Agree 30\%, Slightly Agree 20\%, Slightly Disagree 20\%, Disagree 30\%) Equally. This indicates that there are multiple problems in dealing with suppliers via the Internet for companies. This encourages us the importance of having a model that manages the rating process for all users over the Internet.

Questions 4 to 6 are concerned with measuring the extent of problems caused by online buyers. Such as users not completing their orders, refusing to receive product, and using the product return process a lot. The percentage of those who agree to the fourth question is high, and this is due to a large number of individuals who do not complete their requests for various reasons. This behavior does not significantly affect the design of our model, but put a little weight on it in the rating of individuals. As for the fifth and sixth question (refusal to receive, return of products), even with a low percentage in approval of them, it indicates its importance within the proposed model. As these two process represent a major inconvenience to companies.

For questions 7 to 9 , it measures the percentage of respondents' approval or disapproval, gradually from Strongly Agree\% to Strongly Disagree\%. These questions measure the quality of data exchanged over the Internet and its relevance in building a model that represents a user's creditworthiness. 
The high approval rate for the ninth question indicates that the majority of respondents agree that the user's credit worthiness based on the study of his behavior over the Internet increases individuals' confidence in completing their electronic transaction.

with respect to the yes/no questions, as explained in Fig. 5 , the first and second questions are related to the companies' dealings with suppliers. The responses of the participants confirmed that there are problems with the quality of the products received, as well as financial problems with the suppliers, but in a not large way as it is equal to $27 \%$ of the total percentage. Also, the third question is related to financial problems with corporate buyers, and the percentage has risen slightly to $30 \%$. I think even with low percentages that support the existence of actual problems for companies, the existence of a rating for users through internet will contribute to reducing this percentage significantly while providing protection for these companies.

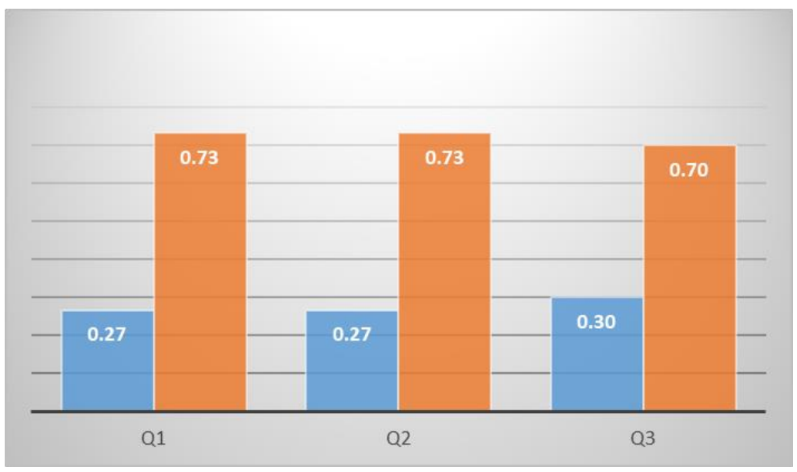

Fig. 5. Percentage Results of Companies and Online Service Providers' Questionnaire Yes/No Part.

3) Results and discussion of the third questionnaire: The third questionnaire related to banking workers or specialists in the field of regulations and laws was applied by 30 of the participants. Table VI, shows the results obtained, also Fig. 6 , shows the percentages of these results for each question. As shown in the Fig. 6, the percentages of the answers to the first question are slightly tilted to refuse to track individuals 'transactions through the Internet. I believe that the percentage of approval also has weight because of the need to track individuals' transactions to prevent crimes. Using of this data was rejected more strongly in the answers to the second question from the participants, due to the sensitivity of not using this data institutionally. From observing the results, the use of this data can be permitted based on strict restrictions on its use. Finally, the answers to the third question tend to deny permission to use this data in the absence of a legal umbrella for this use.

with respect to yes/no questions, Table VII, illustrates the answers of 30 participants. Fig. 7, explain clearly the large percentages of the answer were yes. Where the three questions focus on the importance of the existence of laws and legislation to allow tracking, use and publication of individual transactions over the Internet. Naturally, this segment of the participants was encouraged to issue regulations and legislation that regulate these operations.

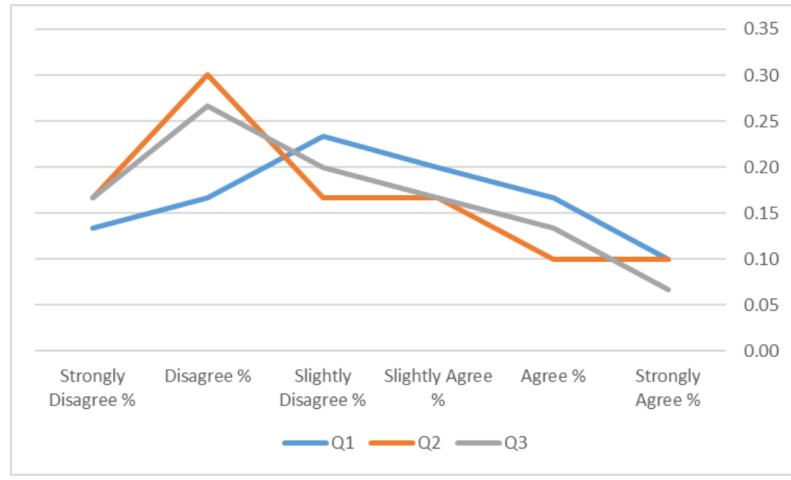

Fig. 6. Percentage Measure for Participants that are familiar with Regulations, Laws and Banking.

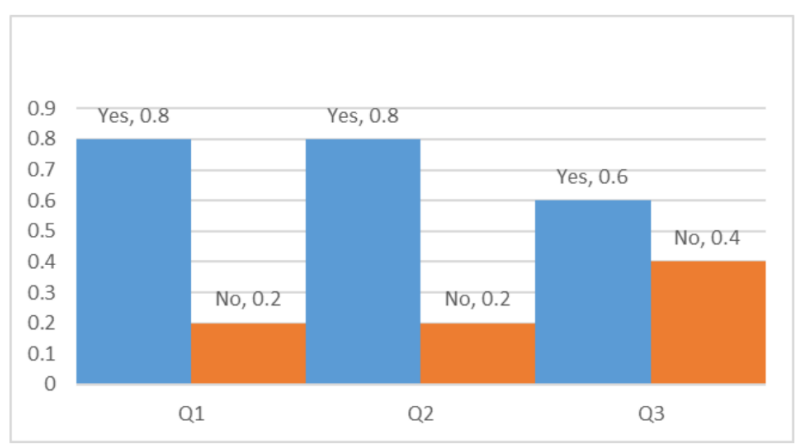

Fig. 7. Percentage Results of Those Are Familiar with Regulations, Laws and Banking Questionnaire Yes/No part.

Based on the results of the third questionnaire, it is clear that it is possible to benefit from individuals' transactions on the Internet to design the proposed model that gives a score for each individual, provided that there are legislations that support and protect the existence of this model.

Based on the results of the third questionnaire, it is possible to benefit from individuals' transactions on the Internet to design the proposed model that gives a score for each individual, provided that there are legislations that support and protect the existence of this model.

\section{DESIGN SCSM}

This model was designed based on the results and discussion of previous questionnaires. Most of the survey results support the existence of the proposed SCSM model, as the results see electronic commerce expanding at increasing rates in the future. The proposed model (SCSM) is illustrated in Fig. 8. First, with regard to our need for regulations and laws, the results of the questionnaire propose that it is better to have controls for tracking, using and disseminating individuals 'data on the Internet. Therefore, a module was added in proposed model that is responsible for monitoring and controlling the use of this data in terms of its size or who is authorized to use it. This module offers the business community a great opportunity to complete its operations with confidence and under a legal umbrella.

Based on the results of the questionnaire, there are problems in buying and selling between individuals and some 
(IJACSA) International Journal of Advanced Computer Science and Applications,

Vol. 12, No. 5, 2021

Table V. Results of Companies and Online Service Providers' Questionnaire Likert Part

\begin{tabular}{|c|c|c|c|c|c|c|c|c|}
\hline Questions & $\begin{array}{l}\text { Strongly } \\
\text { Agree }\end{array}$ & Agree & $\begin{array}{l}\text { Slightly } \\
\text { Agree }\end{array}$ & $\begin{array}{l}\text { Slightly } \\
\text { Disagree }\end{array}$ & Disagree & $\begin{array}{l}\text { Strongly } \\
\text { Disagree }\end{array}$ & Total Response & Results \\
\hline Commercial Transactions & 9 & 6 & 3 & 3 & 6 & 3 & 30 & Accepted \\
\hline Problem with Suppliers & 0 & 9 & 6 & 6 & 9 & 0 & 30 & Not Accepted \\
\hline Income Increasing & 3 & 6 & 15 & 0 & 6 & 0 & 30 & accepted \\
\hline Incomplete Transaction & 6 & 9 & 6 & 0 & 6 & 3 & 30 & Accepted \\
\hline Order Items Refusing & 3 & 3 & 3 & 6 & 15 & 0 & 30 & Not Accepted \\
\hline Product Returning & 0 & 6 & 3 & 6 & 15 & 0 & 30 & Not Accepted \\
\hline Uber History Transaction & 3 & 9 & 3 & 3 & 9 & 3 & 30 & Not Accepted \\
\hline Social Interaction & 6 & 9 & 3 & 3 & 6 & 3 & 30 & Accepted \\
\hline Measure of the User's Credit Worthiness & 9 & 10 & 5 & 0 & 6 & 0 & 30 & Accepted \\
\hline
\end{tabular}

TABle Vi. Results of Those Are Familiar with Regulations, Laws and Banking Questionnaire Likert Part

\begin{tabular}{|c|c|c|c|c|c|c|c|c|}
\hline Questions & $\begin{array}{l}\text { Strongly } \\
\text { Agree }\end{array}$ & Agree & $\begin{array}{l}\text { Slightly } \\
\text { Agree }\end{array}$ & $\begin{array}{l}\text { Slightly } \\
\text { Disagree }\end{array}$ & Disagree & $\begin{array}{l}\text { Strongly } \\
\text { Disagree }\end{array}$ & Total Response & Results \\
\hline Tracking of Electronic Transactions & 3 & 5 & 6 & 7 & 5 & 4 & 30 & Not Accepted \\
\hline Use of Tracked Information & 3 & 3 & 5 & 5 & 9 & 5 & 30 & Not Accepted \\
\hline Without Facing Litigation & 2 & 4 & 5 & 6 & 8 & 5 & 30 & Not Accepted \\
\hline
\end{tabular}

TABLE VII. INTERNET AND SOCIAL USERS QUeSTIONNAIRE YeS/No PART

\begin{tabular}{llll}
\hline Questions & Yes & No & Total Response \\
\hline Law to Tracking Users' Transaction & 24 & 6 & 30 \\
Law to Use Users' Information & 24 & 6 & 30 \\
Law to Publishing Users' Information & 18 & 12 & 30 \\
\hline
\end{tabular}

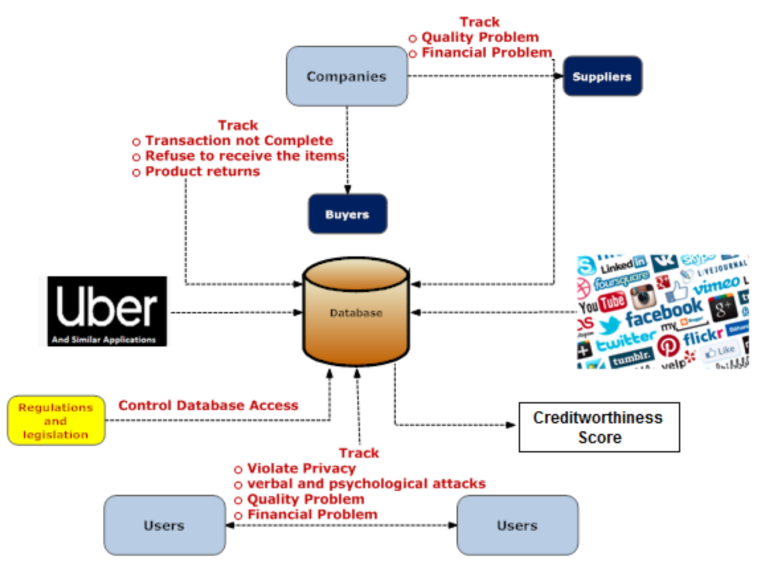

Fig. 8. Designed Model.

of them, which lose the credibility of the transaction that take place over the Internet. Therefore, this data was tracked and added to the model database in order to be used in the creditworthiness of individuals because of its weight according to the analysis of the questionnaires.

There are Another important data that needed to track and add to the model database. For example, verbal and psychological attacks, privacy violation, and data theft. This data has great weight because of its impact on accurately describing the behavior of individuals. Its presence also reduces or eliminates the fear of individuals from online transactions because it adds safety and reliability for the individuals available for transactions.

Today's social media data is very informative. Most people of different ages have multiple social media accounts. With the multiplicity and diversity of this data, our model can rely on it to give an accurate assessment of creditworthiness.

On the other hand, the use of such applications as the Uber application gives important information that reflects the behavior of individuals, whether the individual is the service provider or the beneficiary of it. Tracking this data and recording it in the form database (from discussing the survey results) is very helpful for the final decision describing the creditworthiness of each individual. Therefore, the data for these applications were added to the model as shown in Fig. 8.

\section{CONClusion}

a new concept was introduced to classify individuals in terms of creditworthiness and confidence in dealing with the Internet. This concept was developed to introduce SCSM model in order to be used to increase the reliability of transactions that take place over the Internet. The design of this model relied on collecting multiple data such as social media data, online sales and purchases data, and so on. These data and their degree of importance were determined according to several questionnaires directed to several segments of society.

The first was directed at regular users of the Internet and social media to study the extent of their confidence in transactions that take place over the Internet and what problems they face. As for the second, it was directed at the business community from companies that carry out transactions over the Internet. In this questionnaire, companies' problems with customers and suppliers are studied. Finally, there was a questionnaire directed to banking workers or specialists in the field of regulations and laws. This questionnaire was directed to study the extent of our need for laws regulating the tracking and circulation of information. 
These questionnaires were analyzed and the results of the analysis were used to determine the data that is important to incorporate into the model. Finally, the SCSM was introduced.

\section{A. Future Work}

Developing the SCSM model to make it compatible with the huge development in communications and data transmission will be the focus of our attention in the future. It will be made more flexible to accept and rely on new data that arise from social media and other new services on the Internet.

\section{REFERENCES}

[1] D. M. Boyd and N. B. Ellison, "Social network sites: Definition, history, and scholarship," Journal of Computer-Mediated Communication, 13, 210-230, vol. 13, pp. 210-230, 2008.

[2] Y. Wei, P. Yildirim, C. Van den Bulte, and C. Dellarocas, "Credit scoring with social network data," Marketing Science, vol. 35, no. 2, pp. 234 258, 2016.

[3] S. De Cnudde, J. Moeyersoms, M. Stankova, E. Tobback, V. Javaly, and D. Martens, "What does your facebook profile reveal about your creditworthiness? using alternative data for microfinance," Journal of the Operational Research Society, vol. 70, no. 3, pp. 353-363, 2019.

[4] A. Rona-Tas and A. Guseva, "Consumer credit in comparative perspective," Annual Review of Sociology, vol. 44, pp. 55-75, 2018.

[5] S. D. Cnudde, J. Moeyersoms, MarijaStankova, E. Tobback, VinayakJavaly, and D. Martens, "What does your facebook profile reveal about your creditworthiness? using alternative data for microfinance," Journal of the Operational Research Society, 70:3, 353-363, 2010.

[6] C. V. d. B. Yanhao Wei, Pinar Yildirim, "Credit scoring with social network data," Marketing Science 35(2), 234-258, 2016.

[7] S. . D. G. Goldstein, "Predicting individual behavior with social networks," Marketing Science, vol. 33, pp. 82-93, 2014.
[8] M. Blomberg, "The social credit system and china's rule of law," Mapping China Journal 2: pp. 77-113, 2018.

[9] C. Liu, "Multiple social credit systems in china," Economic Sociology: The European Electronic Newsletter 21 (1): 22-32, 2019.

[10] M. Fourcade and K. Healy, "Classification situations: Life-chances in the neoliberal era," Accounting, Organizations and Society, vol. 38, no. 8, pp. 559-572, 2013.

[11] A. Rona-Tas, "The off-label use of consumer credit ratings," Historical Social Research/Historische Sozialforschung, pp. 52-76, 2017.

[12] G. GUO, F. ZHU, E. CHEN, Q. LIU, L. WU, and C. GUAN, "From footprint to evidence: An exploratorystudy of mining social data for credit scoring..acm transactions on the web," Research Collection School Of Information Systems 10, (4), 22:1-38, 2016.

[13] M. Haenlein and B. Libai, "Targeting revenue leaders for a new product," Journal of Marketing 77 (3), 65-80, 2013.

[14] GuangmingGuo, F. Zhu, E. Chen, L. Wu, Q. Liu, Y. Liu, and MinghuiQiu, "Personal credit profiling via latent user behavior dimensions on social media," In PAKDD 2016. 130-142, 2016.

[15] B. R. Trusov M, Bodpati AV, "Determining influential users in internet social networks," Marketing Res. 47(4): 643-658, 2010.

[16] S. Sevignani, "Surveillance, classification, and social inequality in informational capitalism: The relevance of exploitation in the context of markets in information," Historical Social Research/Historische Sozialforschung, pp. 77-102, 2017.

[17] C. Liu, "Multiple social credit systems in china," Economic Sociology: The European Electronic Newsletter, vol. 21, pp. 22-32, 2019.

[18] M. H. . J. Adebayo, "Credit scoring in the era of big data," Yale Journal of Low. \& Technology, 18, 2017.

[19] N. Raghunath, "A sociological review of china's social credit systems and guanxi opportunities for social mobility," Sociology Compass, vol. 14, no. 5, p. e12783, 2020.

[20] D. Nemoto, T. \& Beglar, "Developing likert-scale questionnaires," JALT2013 Conference Proceedings. Tokyo: JALT, 2014.

\section{APPENDIX}


TABLE VIII. INTERNET AND SOCIAL USERS QUESTIONNAIRE LIKERT PART

\begin{tabular}{|c|c|c|c|c|c|c|c|}
\hline & Questions & $\begin{array}{l}\text { Srtongly } \\
\text { Disagree }\end{array}$ & Disagree & $\begin{array}{l}\text { Slightly } \\
\text { Disagree }\end{array}$ & $\begin{array}{l}\text { Slightly } \\
\text { Agree }\end{array}$ & Agree & $\begin{array}{l}\text { Strong } \\
\text { Agree }\end{array}$ \\
\hline 1 & I use the internet a lot & 1 & 2 & 3 & 4 & 5 & 6 \\
\hline 2 & I use the social media sites a lot & & & & & & \\
\hline 3 & The internet is useful for buying products at a good price & & & & & & \\
\hline 4 & I'm frequently used internet to make purchases and sales processes & & & & & & \\
\hline 5 & I'm frequently used application of technology companies like Uber & & & & & & \\
\hline 6 & It is possible to encounter too many problems during sales through internet & & & & & & \\
\hline 7 & It is possible to encounter too many problems during buying through internet & & & & & & \\
\hline 8 & It is possible to encounter some verbal and psychological attacks on social & & & & & & \\
\hline 9 & I think My privacy can be violated on social media media & & & & & & \\
\hline 10 & I think My personal data can be stolen on internet & & & & & & \\
\hline 11 & I'm frequently executed my banking transactions online & & & & & & \\
\hline 12 & $\begin{array}{l}\text { I believe that transactions via the Internet and social media can extract information that can be used } \\
\text { to build a creditworthiness system similar to that found in banks }\end{array}$ & & & & & & \\
\hline 13 & Total Scores & & & & & & \\
\hline
\end{tabular}

TABLE IX. INTERNET AND SOCIAL USERS QUESTIONNAIRE - Yes/No PART

\begin{tabular}{lll}
\hline & Questions & Yes \\
\hline 1 & Have you encountered problems with the quality of the product received? & No \\
2 & Have you faced financial problems when selling on the Internet? & \\
3 & Have you faced financial problems when buying from the Internet? & \\
\hline
\end{tabular}

TABLE X. INTERNET AND SOCIAL USERS QUESTIONNAIRE - CHOOSE PART

\begin{tabular}{lllll}
\hline & Questions & 1 & 2 & 3 \\
\hline 1 & What is payment method you prefer when you buy something from the internet & visa & when receiving \\
\hline
\end{tabular}

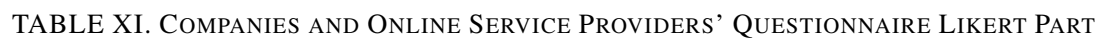

\begin{tabular}{|c|c|c|c|c|c|c|c|}
\hline & Questions & $\begin{array}{l}\text { Srtongly } \\
\text { Disagree }\end{array}$ & Disagree & $\begin{array}{l}\text { Slightly } \\
\text { Disagree }\end{array}$ & $\begin{array}{l}\text { Slightly } \\
\text { Agree }\end{array}$ & Agree & $\begin{array}{l}\text { Strongly } \\
\text { Agree }\end{array}$ \\
\hline 1 & I'm frequently performed commercial transactions through the internet & 1 & 2 & 3 & 4 & 5 & 6 \\
\hline 2 & Dealing with suppliers through the internet has increase the transaction problem & & & & & & \\
\hline 3 & The internet has increased my income & & & & & & \\
\hline 4 & Most of my internet buyers don't complete their transaction & & & & & & \\
\hline 5 & Most of my internet buyers refuse to receive the items & & & & & & \\
\hline 6 & Most of my internet buyers use Product returns process & & & & & & \\
\hline 7 & $\begin{array}{l}\text { I think we can build on people's history of how they treat tech companies apps like Uber to rank a } \\
\text { new customer }\end{array}$ & & & & & & \\
\hline 8 & $\begin{array}{l}\text { I see that we can build on the history of people who interact negatively or positively with social } \\
\text { media in rating a new user customer }\end{array}$ & & & & & & \\
\hline 9 & $\begin{array}{l}\text { I think that the existence of a measure of the user's credit worthiness based on the study of his } \\
\text { behavior over the Internet increases confidence in electronic transactions }\end{array}$ & & & & & & \\
\hline 10 & Total Scores & & & & & & \\
\hline
\end{tabular}

TABle XiI. Companies and Online Service Providers' Questionnaire - Yes/No Part

\begin{tabular}{|c|c|c|}
\hline & Questions & Yes \\
\hline 1 & Have you encountered problems with the quality of the product received from suppliers? & \\
\hline 2 & Have you encountered financial problems when dealing electronically with suppliers? & \\
\hline 3 & Did you encounter financial problems with buyers? & \\
\hline
\end{tabular}


TABLE XiII. Those are Familiar with Regulations, Laws and Banking Questionnaire Likert Part

\begin{tabular}{|c|c|c|c|c|c|c|c|}
\hline & Questions & $\begin{array}{l}\text { Srtongly } \\
\text { Disagree }\end{array}$ & Disagree & $\begin{array}{l}\text { Slightly } \\
\text { Disagree }\end{array}$ & $\begin{array}{l}\text { Slightly } \\
\text { Agree }\end{array}$ & Agree & $\begin{array}{l}\text { Strong } \\
\text { Agree }\end{array}$ \\
\hline 1 & I think it is possible to allow tracking of electronic transactions of users over the Internet & 1 & 2 & 3 & 4 & 5 & 6 \\
\hline 2 & I think it is possible to allow the use of this information gathered online & & & & & & \\
\hline 3 & I think it is possible to use this information without facing litigation in the future & & & & & & \\
\hline 4 & Total Scores & & & & & & \\
\hline
\end{tabular}

TABLE XIV. Those are Familiar with Regulations, Laws and Banking Questionnaire - Yes/No Part

\begin{tabular}{lll}
\hline & Questions & Yes \\
\hline 1 & We need laws that manage the process of tracking users' electronic transactions & No \\
2 & We need laws that manage the use of information about users \\
3 & We need laws that manage the process of publishing information about users & \\
\hline
\end{tabular}

